\title{
Secularism as Related to Gender and Religion
}

\author{
Dr. Shashi Kala Singh ${ }^{1}$, Mrs. Pushpa Singh ${ }^{2}$
}

\section{ABSTRACT}

The aim of the present study was to examine the gender and religion difference in secularism. Participants were 100 school students belong to Ranchi town (50 boys \& 50 girls) of age range 13 to 16 years. All of these belong to middle socio-economic status. Respondents were given secularism scale. Data was analyzed by using means, standard deviations and " $\mathrm{t}$ ". The mean of male student was 31.53and female student was 29.97. The difference between the means was insignificant. Boys and girls showed similar level of secularism.Christian group showed significantly higher level of secularism than Muslim group.

Keywords: Secularism, Gender, religion and middle socio-economic status.

India has a composite population. The Indian society is diverse for as there exist numerous religious, cultural and linguistic groups. There are Hindus, Muslims, Christians, Parsis, Sikhs Buddhists, Jains and others. The pattern of culture varies from place to place. India is a Socialist, Secular Democratic Republic pledged to secure all its citizens justice, liberty and equality and to promote fraternity among nationals. Secularism is the principle of separation of government institutions, and the persons mandated to represent the State, from religious institutions and religious dignitaries. The Indian concept of secularism which advocates a non-sectarian attitude towards religion and encourages the process of dialogue and interdependence among faiths, the French model of laicite envisages a radical separation between politics and religion in the name of progress and the rights of a universal man whom no one has seen. India is a secular country as per the declaration in the Preamble to the Indian Constitution. It prohibits discrimination against members of a particular religion, race, caste, sex or place of birth. In India, secular tradition is deep rooted in its history. Indian culture is a composite one which is based on the blending of various spiritual traditions and social movements. In ancient India, Hinduism was basically allowed to develop as a holistic religion by welcoming different spiritual traditions and trying to integrate them into a common mainstream.

\footnotetext{
${ }^{1}$ Associate Professor, Dept. of Psychology, Ranchi University, Ranchi

${ }^{2}$ Asst. Professor, Dept. of Psychology, Ranchi Women's College, Ranchi
} 


\section{Secularism as Related to Gender and Religion}

The development of four Vedas and the various interpretations of the Upanishads and the Puranas clearly highlight the religious plurality of Hinduism. In a secular state, no one would enjoy any special privilege in national life or in the conduct of international relations. No group of citizens shall arrogate to itself the rights and privileges which it denies to others. No person shall suffer any form of disability or discrimination because of his religion but all alike should be free to share to the fullest degree in the common life. We in India have tried to follow a secular path, although we had some setbacks from time to time. Secularism has deep implications in our day-to-day life. Secularism has its origin in western countries and relates to the separation of the church from the state, giving the state a position of neutrality between different religions, while at the same time, guaranteeing all citizens the right to profess any one of them. Positive Ideals behind the secular society:

1. Deep respect for individuals and the small groups of which they are a part.

2. Equality of all people.

3. Each person should be helped to realize their particular excellence.

4. Breaking down of the barriers of class and caste

Secularism is a code of duty pertaining to this life, founded on considerations purely human, and intended mainly for those who find theology indefinite or inadequate, unreliable or unbelievable.Recent cross-sectional evidence (Flor\& Knapp, 2001) suggests that religious socialization may be more effective for boys than for girls. Men dominated all varieties of secularism until the late 20th century. While men owned the pulpit, women and girls dominated the pew. They were the backbone of the churches and of household religion (Wood, 1975). The history of secularization is a more complicated process than is indicated by stark contrasts between "the religious" and "the secular" (Scott, 2010). Choudhary (1979) found that there was a very significant difference in religious and secular concept of the pupils of denominational and non-denominational school, the former having more religious concepts and less secular concept than the later. The only way to heal the rifts within the secular community is for mainstream secularists to realize that they, too, are feminists, and present a united front against harassment and intimidation within our movement (Kincaid, 2013). Feminism is a social and political movement for gender equality, a movement with deep historical connections to American free thought.

Singh (1978) conducted a study on development of religious identity and prejudice in Indian children. The sample consisted of 300 students from Non-Muslim and Muslim aged 4-5 to 14-15. The investigator found that religious information about one's own religion and others increased with the age and by 14-15 years it gets completed.Sumbul (2002) measured the secular attitude of the students studying in two denominational schools. The sample consisted of 300 students out of which 150 were from Muslim managed organizations and 150 were from non-Muslim managed organizations. The investigator found out that there is no significant difference in the secular attitude of students studying in Muslim and Non-Muslim managed institution. 


\section{Secularism as Related to Gender and Religion}

\section{HYPOTHESES}

- There will be no difference between boys and girls in secularism

- There will be no difference between Muslim and Christian students in secularism

\section{METHOD}

\section{Sample}

One hundred school students from different schools of Ranchi town participated in this study. They were selected using a stratified random sampling technique. There were 50 boys and 50 girls respondents ofage-group 13 to 16 years. The sample was further sub-divided into Muslim and Christian group.All of these belong to middle socio-economic status.

\section{Instrument}

Secularism Scale: This tool has been used in this research developed in the Post Graduate Department of Psychology, Ranchi University, Ranchi. The tools were developed for the ICSSR Research Project on "Prejudice in Indian Children" and have been reported to be highly reliable and valid (Singh, 1980). The Secularism scale consists of 15 items in a 5 - point Likert type scale. The strongly favourable response of a positive item will fetch the score of 1 and the strongly unfavourable response of a positive item will fetch the score of 5 . Likewise the favourable and unfavourable responses will fetch the score of 4 and 2 respectively. However, the neutral or uncertain response will get the score of 3 . The scoring of negative items will be just reverse of the positive items. Thus, the higher scores indicated lower degree of secularism.

\section{Procedure}

The secularism scale was administered to both groups with instructions to complete all questions honestly and not to discuss the questions with fellow students. Scoring was done according to the respective scoring keys. In order to fulfill the objective of the study the score obtained were analyzed with mean, SD's and t values.

\section{RESULT AND DISCUSSION}

The data wasanalysed by Means, SDs and t test. Tables present the result.

Table -1

\section{Means, SDs and t-value of boys and girls group on secularism}

\begin{tabular}{|c|c|c|c|c|c|c|}
\hline Groups & N & Mean & SDs & MD & t & P value \\
\hline Boys & 50 & 31.53 & 6.93 & \multirow{2}{*}{1.56} & 0.82 & $\begin{array}{c}\text { Not } \\
\text { Significant }\end{array}$ \\
\hline Girls & 50 & 29.97 & 6.74 & & &
\end{tabular}

It was evident from the above table that there was no significant difference between boys and girls in secularism. Girls group showed slightly lower score than their boy counterparts, but their difference was not statistically significant even at 0.05 level of significance. Hence, the 


\section{Secularism as Related to Gender and Religion}

hypothesis there will be no difference between boys and girls in secularism was accepted.The results were in agreement with earlier findings of Avishai (2008).

Table -2

Means, SDs and t-value of Muslim and Christian group on secularism

\begin{tabular}{|c|c|c|c|c|c|c|}
\hline Groups & N & Mean & SDs & MD & t & P value \\
\cline { 1 - 4 } Muslim & 50 & 34.12 & 6.27 & \multirow{2}{*}{5.64} & 3.97 & \multirow{2}{*}{0.01} \\
\hline Christian & 50 & 28.48 & 7.93 & & & \\
\hline
\end{tabular}

Table -2 indicated that Muslim and Christian groups differ significantly in their mean scores. Christian group showed higher levels of secularism than their Muslim counterpart. Hence the hypothesis, there will be no difference between Muslim and Christian students in secularism, was rejected. Religion had a significant influence in secularism.

\section{CONCLUSIONS}

- Boys and girls group displayed similar level of secularism.

- Christian groupdisplayed more secularism than Muslim group.

\section{REFEREENCES}

Avishai, O. (2008). Doing Religion in a secular world women in conservative religions and the question of agency, Gender \& Society, 22(4) 409-433

Choudhary, R.N. (1979). The study of religious education in school of Bombay with special reference to its impact on secular concept of pupils, Bombay Univ. Ph.D.

Flor, D. L., \& Knapp, N. F. (2001). Transmission and transaction: Predicting adolescents' internalization of parental religious values. Journal of Family Psychology, 15, 627-645.

Kincaid.T.J. (2013).The failure of feminism, Journal of Personality and Social Psychology.10,335-342.

Scott, J. (2010). Explores the relationship between Secularism and gender equality.Secularism, Washington History Seminar.

Singh, A.K. (1978). Development of religious identity and prejudice in Indian children, Ranchi Univ. Ph.D.

Sumbul, S. (2002).A comparative study of the secular attitude of the students studying in two denominational schools, A.M.U., M.Ed.

Wood.G.A. (1975).Church and state in New Zealand in the 1850s.Journal of Religious History.8 (3) 255. 